\title{
FAKTOR YANG MEMPENGARUHI MOTIVASI WISATAWAN KE DESA WISATA LIANG NDARA KABUPATEN MANGGARAI BARAT
}

\author{
Viktorianus Walbat ${ }^{1}$, Putu Agus Wikanatha Sagita ${ }^{2}$, N.M.S. Wijaya ${ }^{3}$ \\ Email: viktorianuswalbat@yahoo.com¹, aguswika@unud.ac.id ${ }^{2}$, sofia_ipw@unud.ac.id ${ }^{3}$ \\ 1,2,3Program Studi Industri Perjalanan Wisata, Fakultas Pariwisata, Universitas Udayana
}

\begin{abstract}
This research was conducted to analysis the factors that influence the motivation of tourists, and to find out the dominant factors that influence the motivation of tourists visiting the Liang Ndara Tourism village of Manggarai Barat Regency. Determination of the sample for tourists using the Accidental sampling method, the analysis technique used in this study is a descriptive quantitative analysis technique with validity, reliability and factor analysis supported by SPSS version 21.0.The result examined of factor analysis, there are three factors that influence the motivation of tourists to visit Liang Ndara Tourism Village, (1) Quality of Facilities Factors consisting of six indicators, namely the availability of public facilities such as toilets and parking area, escape from urban routine, hand-woven crafts and traditional woven textiles made by local, the uniqueness of cultural attractions such as the Caci dance or traditional dance by Manggarai Barat people, the security, natural resources such as waterfall and protected forest, (2) The second factor is Rest and Relaxation factor, which consists of six indicators, namely the desire for physical and mental refreshment, the desire to interact socially with the local community, breaking away from routine work, Liang Ndara Tourism Village location easy to access by vehicle, restaurants facility, Availability of Lodging / accommodation. (3) The third factor is Realize Dreams factor, which consists of two indicators, namely fulfillment of travel dreams, and the desire to visit friends or relatives. The dominant factor of the three factors above is Quality of Facilities.
\end{abstract}

\begin{abstract}
Abstrak: Penelitian ini dilakukan untuk menganalisis faktor-faktor yang mempengaruhi motivasi wisatawan berkunjung dan untuk mengetahui faktor dominan yang mempengaruhi motivasi wisatawan berkunjung ke desa Wisata Liang Ndara Kabupaten Manggarai Barat. Penentuan sampel untuk wisatawan menggunakan metode Accidental sampling, teknik analisis yang digunakan dalam penelitian ini adalah teknik analisis deskriptif kuantitatif degan uji validitas, reliabilitas dan analisis faktor yang dibantu dengan program SPSS versi 21.0.Berdasarkan hasil uji dari analisis faktor terdapat tiga faktor yang mempengaruhi motivasi wisatawan berkunjung ke Desa Wisata Liang Ndara yaitu (1) Faktor Kualitas Fasilitas yang terdiri atas enam indikator yaitu tersedianya fasilitas- fasilitas umum seperti toilet dan tempat parkir, melepaskan diri dari rutinitas kehidupan perkotaan, kerajinan tangan berupa tenun dan anyaman yang dibuat secara tradisional, keunikan atraksi budaya seperti tarian Caci atau tarian tradisional orang Manggarai, keamanan, keindahan alam seperti air terjun dan hutan lindung, (2) Faktor kedua faktor Istirahat dan Relaksasi, yang terdiri atas enam indikator yaitu keinginan untuk penyegaran fisik dan mental, keinginan berinteraksi sosial dengan masyarakat lokal, melepaskan diri dari rutinitas pekerjaan, lokasi mudah dijangkau dengan kendaraan, tersedianya rumah makan, tersedianya penginapan. (3) Faktor ketiga faktor Mewujudkan Impian, yang terdiri atas dua indikator yaitu merealisasikan mimpi-mimpi yang lama di cita-citakan, dan keinginan mengunjungi teman atau krabat. Adapun faktor dominan dari tiga faktor diatas adalah faktor kualitas fasilitas.
\end{abstract}

Keywords: factor analysis, liang ndara tourism village, tourist motivation. 


\section{PENDAHULUAN}

Pariwisata merupakan kegiatan melakukan perjalanan dengan tujuan mendatangkan kesenangan, mencari kepuasan, mencari sesuatu dan memperbaiki kesehatan, menikmati olahraga atau istirahat, menunaikan tugas, berziarah dan lain-lain (Spilane, 2001). Pariwisata memiliki peranan penting dalam pembangunan nasional sebagai penghasil devisa, memeratakan dan meningkatkan kesempatan kerja dan meningkatkan pendapatan masyarakat. Pembangunan pariwisata dapat berkembang karena adanya dukungan dan partisipasi dari berbagai pihak baik wisatawan, masyarakat, pemerintah, maupun pihak swasta. Secara ekonomi pariwisata memberi dampak dalam perluasan lapangan usaha dan kesempatan kerja, peningkatan income per kapita dan peningkatan devisa negara.

Indonesia sebagai negara berkembang merupakan salah satu negara yang begitu giat dalam membangun sektor pariwisata. Selain memiliki potensi yang besar seperti minyak bumi, gas alam, batu bara dan lain-lain. Indonesia juga memiliki potensi dalam sektor pariwisata. Ragam budaya, keindahan alam merupakan faktor atau aset berharga dalam pengembangan pariwisata. Menurut UndangUndang No. 10/2009 tentang kepariwisataan yang dimaksud dengan Pariwisata adalah berbagai macam kegiatan wisata yang didukung berbagai fasilitas serta layanan yang disediakan masyarakat, pengusaha, Pemerintah dan Pemerintah Daerah. Pariwisata Indonesia juga sangat berkembang cukup pesat, karena dilihat dari bentuknya sebagai negara kepulauan yang memiliki banyak pulau dengan keindahan alam dan daya tarik tersendiri disetiap daerahnya. Berkembang pesatnya pariwisata Indonesia tentunya didukung dengan pembangunan fasilitas-fasilitas pendukung dalam pengembangan pariwisata dan pemerintah juga ikut bekerjasama dengan masyarakat lokal dalam pengembangan daerah tujuan wisata yang ada di Indonesia.

Berkembangnya sektor pariwisata Indonesia membuat kunjungan wisatawan setiap tahunnya meningkat dan tersebar dibeberapa provinsi diantaranya di bagian timur Nusa Tenggara Indonesia, salah satunya adalah Provinsi Nusa Tenggara Timur. Provinsi Nusa
Tenggara Timur merupakan wilayah kepulauan yang terdiri dari 1.942 pulau, 432 diantaranya sudah mempunyai nama dan sisanya sampai saat ini belum mempunyai nama. Diantara yang sudah mempunyai nama terdapat 4 pulau besar yaitu Flores, Sumba, Timor dan Alor (FLOBAMORA). Pemerintah Provinsi Nusa Tenggara Timur (NTT) saat ini cendrung mempersiapkan wilayahnya untuk menjadi daerah tujuan wisata dunia yang baru. Sejak ditetapkanya Taman Nasional Komodo sebagai salah satu The New Seven Wonders Of Nature (tujuh keajaiban dunia yang baru ), maka NTT akan menjadi salah satu pintu masuk pariwisata Indonesia yang baru selain Bali, yang sudah sangat di kenal selama ini. Kunjungan wisatawan ke provinsi Nusa Tenggara Timur tersebar di beberapa destinasi wisata dan kebanyakan wisatawan yang berkunjung ke provinsi ini, berkunjung ke pulau Flores.

Disetiap Kabupaten yang ada di pulau Flores masing-masing memiliki keunikan dan keunggulan tersendiri, dan yang sangat terkenal di kalangan wisatawan adalah kabupaten Mangagarai Barat yang memiliki salah satu destinasi yang merupakan tujuh keajaiban dunia yang baru yaitu Taman Nasional Komodo (TNK). Destinasi wisata lainnya juga mampu menarik wisatawan berkunjung ke Kabupaten Manggarai Barat dan salah satunya adalah Desa Wisata Liang Ndara,

Desa Wisata Liang Ndara merupakan desa binaan dari Indonesia Ecotourism Network, masyarakat di desa ini mempertunjukkan budaya dan tarian Flores dan Tarian Caci menjadi daya tarik utama dari Desa Liang Ndara. Desa wisata Liang Ndara juga memiliki daya Tarik pendukung untuk dikunjungi wisatawan seperti, hutan Mbeliling, dan beberapa air terjun yaitu Air Terjun Liang Kantor, Air Terjun Wae Rebus, dan Air Terjun Wae Satar. Wisatawan yang berkunjung ke Desa Wisata Liang Ndara juga dapat menjumpai proses pembuatan kain tenun dan anyaman dengan cara tradisional yang dilakukan oleh masyarakat lokal dan bisa membelinya sebagai oleh-oleh. Untuk mencapai lokasi Desa Wisata Liang Ndara membutuhkan waktu 45 menit perjalanan dari pusat kota Labuan Bajo dengan jarak $20 \mathrm{~km}$. Berikut adalah data kunjungan wisatawan Mancanegara dan Nusantara yang berkunjung 
ke Desa Wisata Liang Ndara selama lima tahun terakhir.

Tabel 1

Jumlah Kunjungan Wisatawan Mancanegara Dan Nusantara Ke Desa Wisata Liang Ndara Tahun 2013-2017

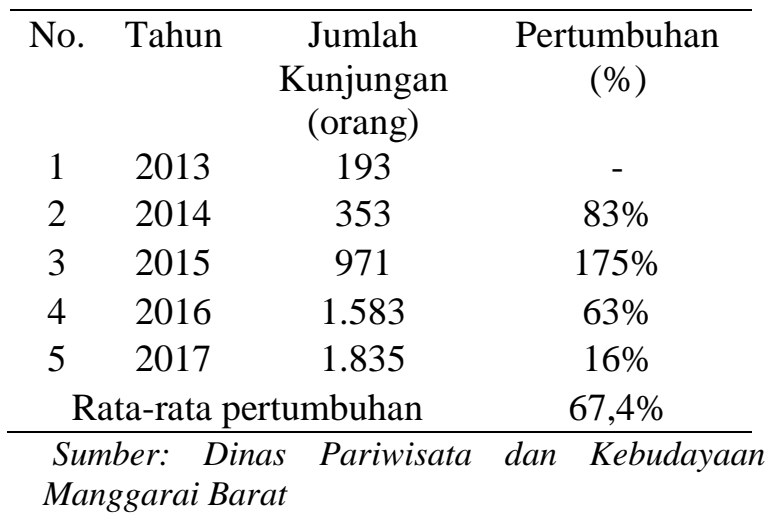

Berdasarkan tabel 1 menunjukkan jumlah kunjungan wisatawan yang berkunjung ke Desa Wisata Liang Ndara setiap tahun mengalami peningkatan dengan rata-rata pertumbuhan mencapai $67,4 \%$.

Dengan potensi wisata yang dimiliki oleh Desa Wisata Liang Ndara seperti keunikan atraksi budaya, kesenian, adat istiadat dan juga keindahan alam yang ada, membuat kunjungan wisatawan ke desa ini setiap tahunnya meningkat. Meningkatnya data jumlah kunjungan wisatawan tersebut, tentunya tidak terlepas dari pengelolaan dan pengembangan Desa Wisata Liang Ndara sebagai salah satu desa wisata yang mampu menarik wisatawan berkunjung, dan jika dilihat dari Golden route wisatawan berkunjung ke Kabupaten Manggarai Barat. Sebagai salah satu Golden Route wisatawan berkunjung ke Kabupaten Manggarai Barat, Desa Wisata Liang Ndara adalah satu-satunya desa wisata yang menawarkan budaya asli Manggarai Barat, sehingga jika wisatawan ingin berkunjung ke Kabupaten Manggarai Barat maka, Desa Wisata Liang Ndara merupakan tujuan yang tepat jika wisatawan ingin mengenal budaya yang ada di Kabupaten Manggarai Barat.

Oleh karena itu perlu dilakukan penelitian mengenai motivasi wisatawan berkunjung ke Desa Wisata Liang Ndara, yang nantinya akan dijadikan sebagai bahan evaluasi dan dasar untuk pengelolaan dan pengembangan Desa Wisata Liang Ndara kedepanya, dan juga menjadi alasan peneliti meneliti tentang "Faktor-faktor yang mempengaruhi motivasi wisatawan berkunjung ke Desa Wisata Liang Ndara Kabupaten Manggarai Barat".

\section{METODE}

Studi ini dilakukan dilakukan untuk mengetahui faktor-faktor yang mempengaruhi motivasi wisatawan berkunjung ke Desa Wisata Liang Ndara Kabupaten Manggarai Barat Serta faktor yang mendominasi motivasi wisatawan berkunjung ke Desa Wisata Liang Ndara. Variabel yang digunakan adalah variabel motivasi yang dibagi menjadi menjadi dua sub variabel yaitu variabel faktor pendorong meliputi: Escape, Relaxation, Strengthening family bounds, prestige, social interaction, wish fulfillment (Ryan dalam I Gede Pitana, 2005). Serta sub variabel faktor penarik meliputi: Aksesibilitas, ketersedian jasa atau service, satabilitas politikdan keamanan, ketersediaanya atraksi (Weaver \& Lowton dalam Giva Pavule, 2006).

Untuk mendapatkan data dalam studi ini digunakan beberapa teknik pengumpulan data antara lain: observasi, kuesioner, wawancara, kepustakaan dan dokumentasi.

Studi ini menggunakan menggunakan kuesioner yang dibagikan kepada wisatawan yang berkunjung ke Desa Wisata Liang Ndara. Penentuan jumlah sampel menggunakan teori dari Umar (2005) yaitu untuk menentukan jumlah sampel dari wisatawan digunakan rumus slovin dengan tingkat kesalahan $10 \%$, maka jumlah sampel yang digunakan dalam penelitian ini adalah sebanyak 100 orang wisatawan.

Dalam studi ini terdapat dua sub variabel yaitu faktor pendorong dan faktor penarik. Kedua sub variabel ini kemudian dipecah menjadi 15 indikator. Untuk mendapakan jumlah responden maka ukuran sampel dalam penelitian ini dapat diketahui dengan cara melihat hasil dari rumus slovin yaitu kuesiner dibagikan kepada 100 orang wisatawan Yang berkunjung ke Desa Wisata Liang Ndara.

Teknik analisis yang digunakan pad studi ini adalah analisis deskriptif kuantitatif. Metode ini digunakan untuk menganalisis motivasi wisatawan berkunjung ke Desa Wisata 
Liang Ndara. kemudian dilakukan teknik analisis data dengan mengolah data melalui program SPSS Versi 21.0. Adapun penjabaran pengolahan data analisis faktor terdiri atas: uji KMO dan Barletts test, uji Measure of Sampling Adequancy (MSA), menentukan jumlah faktor, rotasi faktor, dan interpretasi faktor.

\section{PEMBAHASAN}

Desa wisata Liang Ndara adalah salah satu desa wisata yang ada dikabupaten Manggarai Barat. Sebagian besar wisatawan yang berkunjung ke Desa wisata Liang Ndara sudah dipastikan adalah mereka yang ingin menikmati kebudayaan tradisional atau daya tarik wisata budaya yang merupakan daya tarik utama Desa Wisata Liang Ndara. selain daya tarik wisata budaya, terdapat juga daya tarik lain yang ada di Desa Wisata Liang Ndara yaitu menikmati keindahan alam diantaranya adalah air terjun dan huatan lindung. Pada umumnya, kondisi wilayah Desa Liang Ndara berbukitbukit yang dipenuhi pepohonan. Desa Liang Ndara sendiri terletak pada $600-1.200 \mathrm{~m}$ di atas permukaan air laut dengan rerata suhu berkisar antara 25 - $370 \mathrm{C}$. Khusus untuk dataran rendah dan lembah dimanfaatkan oleh masyarakat untuk areal permukiman, tanaman pangan, hortikultura, dan perkebunan. Kawasan dataran tinggi, perbukitan, dan lereng dari Gunung Mbeliling mendominasi kondisi fisik Desa Liang Ndara. Gunung Mbeliling adalah kawasan resapan air di dataran tinggi Manggarai yang merupakan sumber mata air bagi kawasan sekitarnya termasuk kota Labuan Bajo.

\section{Karakteristik Wisatawan Yang Berkunjung Ke Desa Wisata Liang Ndara}

1. Jika dilihat dari karakteristik wisatawan yang berkunjung ke Desa Wisata Liang Ndara berdasarkan daerah asal wisatawan maka wisatawan yang paling mendominasi tingkat kunjungan adalah wisatawan yang bersal dari Australia, dengan persentase mencapai $23 \%$.

2. Berdasarkan jenis kelamin wisatawan yang berkunjung ke Desa Wisata Liang Ndara, wisatawan berjenis klamin laki-laki yang mendominasi karakteristik kunjungan wisatawan berkunjung ke Desa Wisata Liang Ndara, dengan persentase mencapai $58 \%$.
3. Jika dilihat dari karakteristik wisatawan berdasarkan umur, maka dapat disimpulkan wiatawan yang berkunjung ke Desa Wisata Liang Ndara didominasi oleh wisatawan yang berumur 20-35 tahun, dengan persentase mencapai $67 \%$.

4. Jika dilihat dari karakteristik wisatawan berdasarkan pekerjaan, maka dapat disimpulkan wiatawan yang berkunjung ke Desa Wisata Liang Ndara didominasi oleh wisatawan yang yang memiliki pekerjaan sebagai karyawan, dengan persentase mencapai $55 \%$.

5. Jika dilihat dari karakteristik wisatawan berdasarkan pendidikan, maka dapat disimpulkan wiatawan yang berkunjung ke Desa Wisata Liang Ndara didominasi oleh wisatawan yang yang memiliki pendidikan sebagai sarjana dengan persentase mencapai $93 \%$.

6. Jika dilihat dari karakteristik wisatawan berdasarkan status perkawinan, maka dapat disimpulkan wiatawan yang berkunjung ke Desa Wisata Liang Ndara didominasi oleh wisatawan yang yang memiliki status perkwinan sudah kawin, dengan persentase mencapai $73 \%$.

7. Jika dilihat dari karakteristik wisatawan berdasarkan lama tinggal, maka dapat disimpulkan wiatawan yang berkunjung ke Desa Wisata Liang Ndara didominasi oleh wisatawan yang yang memiliki lama tinggal $>1$ minggu dengan persentase mencapai $61 \%$.

8. Jika dilihat dari karakteristik wisatawan berdasarkan penyelenggara perjalanan, maka dapat disimpulkan wisatawan yang berkunjung ke Desa Wisata Liang Ndara didominasi oleh wisatawan yang menggunakan agen perjalanan dengan persentase mencapai $76 \%$.

9. Jika di lihat dari jumlah wisatawan yang berkunjung ke Desa Wisata Liang Ndara berdasarakan tujuanya berkunjung didominasi oleh wisatawan yang berlibur atau berwisata dengan persentase mencapai $100 \%$.

10. Jika dilihat dari jumlahnya wisatawan yang mendominasi berkunjung ke Desa Wisata Liang Ndara Berdasarkan sumber informasi adalah wisatawan yang mengetahui Desa Wisata Liang Ndara dari Agen Perjalanan dengan persentase mencapai $48 \%$. 
11. Karakteristik wisatawan yang berkunjung ke Desa Wisata Liang Ndara jika dilihat berdasarkan frekuensi kunjungan, hasil dari 100 responden yang berkunjung, yaitu baru pertama kali berkunjung Ke Desa Wisata Liang Ndara atau dengan persentase mencapai $100 \%$.

12. Karakteristik wisatawan yang berkunjung ke Desa Wisata Liang Ndara berdasarkan denga siapa berkunjung, dapat diketahui bahwa, wisatawan yang mendominasi yaitu berkunjung dengan keluaraga dengan persentase mencapai $74 \%$.

13. Jika dilihat dari jumlahnya maka wisatawan yang mendominasi berkunjung ke Desa Wisata Liang Ndara Berdasarkan transportasi yaitu wisatawan yang menggunakan mobil, dengan persentase mencapai $86 \%$.

\section{Faktor-Faktor Yang Mempengaruhi Motivasi Wisatawan Berkunjung Ke Desa Wisata Liang Ndara Uji Validitas}

Uji validitas digunakan untuk mengetahui valid atau tidaknya sebuah index atau instrument yang di teliti. Instrument tersebut dikatakan valid apabila koefisienya sama dengan 0,3 atau lebih. Jika di bawah angka tersebut maka data dikatakan tidak relavan untuk di teliti lebih lanjut (Sugiyono 2013:179).

Tabel 2

Hasil Uji Validitas

\begin{tabular}{lccc}
\multicolumn{1}{c}{ Indikator } & $\begin{array}{c}\mathbf{r} \\
\text { hitung }\end{array}$ & $\begin{array}{c}\mathbf{r} \\
\text { tabel }\end{array}$ & Ket \\
$\begin{array}{l}\text { Melepaskan diri dari } \\
\text { Rutinitas kehidupan } \\
\text { perkotaan (X1) }\end{array}$ & 0,568 & $>0,3$ & Valid \\
$\begin{array}{l}\text { Melepaskan diri dari } \\
\text { rutinitas pekerjaan } \\
\text { (X2) }\end{array}$ & 0,733 & $>0,3$ & Valid \\
$\begin{array}{l}\text { Keinginan untuk } \\
\text { penyegaran fisik dan } \\
\text { mental (X3) }\end{array}$ & 0,697 & $>0,3$ & Valid \\
$\begin{array}{l}\text { Keinginan } \\
\text { mengunjungi teman }\end{array}$ & 0,769 & $>0,3$ & Valid \\
atau krabat (X4) & & & \\
$\begin{array}{l}\text { Untuk menunjukan } \\
\text { Gengsi (X5) }\end{array}$ & 0,472 & $>0,3$ & Valid \\
$\begin{array}{l}\text { Keinginan } \\
\text { berinteraksi }\end{array}$ & 0,375 & $>0,3$ & Valid \\
$\begin{array}{l}117 \text { ocal117 dengan } \\
\text { masyarakat 117ocal di }\end{array}$ & & & \\
$\begin{array}{l}\text { Desa Wisata Liang } \\
\text { Ndara (X6) }\end{array}$ & & &
\end{tabular}

Merealisasikan

$0,529 \quad>0,3 \quad$ Valid

mimpi-mimpi yang

lama di cita-citakan

(X7)

Lokasi Desa Wisata

Liang Ndara mudah

dijangkau dengan

kendaraan (X8)

Tersedianya Rumah

makan di di sekitar

Desa Wisata Liang

Ndara (X9)

Tersedianya

Penginapan di sekitar

Desa Wisata Liang

Ndara (X10)

Tersedianya Fasilitas-

fasilitas umum seperti

toilet dan tempat

parkir di Desa Wisata

Liang Ndara (X11)

Keamanan saat berada

di Desa Wisata Liang

Ndara (X12)

Keunikan atraksi

budaya seperti tarian

Caci atau tarian

tradisional orang

Manggarai (X13)

Kerajinan tangan

berupa tenun dan

anyaman yang dibuat

secara tradisional di

Desa Wisata Liang

Ndara (X14)

Keindahan Alam

disekitar Desa Wisata

Liang Ndara seperti

air Terjun dan hutan

lindung (X15)

Sumber: Hasil pengolahan data tahun 2019

Berdasarkan tabel Hasil uji validitas, dapat diketahui terdapat 15 indikator yang diuji validitasnya dan sesuai dengan persyaratan bahwa variabel yang memiliki nilai koefisien sama atau lebih dari 0,3 dinyatakan valid, dan dapat di uji keabsahanya, dan juga layak untuk dilanjutkan.

\section{Uji Reliabilitas}

Fungsi dari uji reliabilitas ini dilakukan untuk memperoleh hasil studi yang reliabel. Instrument yang memiliki nilai Cronbach's Alpha sama atau lebih dari 0,6 maka instrument tersebut dinyatakan reliable. 


\section{Hasil Uji Relibilitas \\ Cronbach's Alpha N of Items

$$
913 \quad 15
$$

Sumber: Hasil pengolahan data tahun 2019

Berdasarkan tabel hasil uji reliabilitas dengan menggunakan kuesioner dengan ukuran sampel sebanyak 100 responden menunjukkan bahwa angka dari nilai alpha Cronbach's sebesar 0,913 yang berarti nilai tersebut telah memenuhi syarat atau reliable lebih besar 0,6. Hal ini menunjukkan bahwa kuesioner yang telah diuji dapat memberikan hasil yang konsisten bila nantinya dilakukan pengujian atau pengukuran kembali.

\section{Analisis Faktor}

Hal ini bertujuan untuk mengetahui faktor - faktor yang mempengaruhi wisatawan berkunjung ke Desa Wisata Liang Ndara Kabupaten Manggarai Barat dan faktor paling dominan yang mempengaruhi wisatawan berkunjung ke Desa Wisata Liang Ndara Kabupaten Manggarai Barat yang dapat dijelaskan sebagai berikut:

\section{Uji KMO dan Bartlett's Test}

Hasil analisis uji KMO dan Bartlett's Test faktor pendorong pada studi ini dapat dijelaskan pada tabel 4 berikut:

Tabel 4

\begin{tabular}{lrr}
\multicolumn{3}{c}{ Tabel Uji Bartlett's Dan Uji KMO } \\
\hline \multicolumn{3}{c}{ KMO and Bartlett's Test } \\
Kaiser-Meyer-Olkin Measure of Sampling & .812 \\
Adequacy. & \\
Bartlett's Test of & Approx. Chi-Square & 1422.816 \\
Sphericity & Df & 105 \\
& Sig. & .000 \\
\hline Sumber: Hasil pengolahan data tahun 2019
\end{tabular}

Berdasarkan tabel 4.17 dapat diketahui nilai Bartlett's Test of Sphericity yang diperoleh adalah 1422,816 dengan signifikasi 0,000. Hasil ini menujukkan bahwa antara variable terjadi korelasi dan dengan demikian peluang untuk terjadinya kesalahan pada variabel yang tidak independen sebesar $0 \%$.

\section{Uji MSA (Measure of Sampling Adequacy)}

Hasil analisis uji MSAfaktor pendorong pada studi ini dapat dijelaskan pada tabel 5 berikut:
Nilai MSA Dengan 15 Indikator Pada Anti-Images Matrices

\begin{tabular}{|c|c|c|c|}
\hline No & Indikator & $\begin{array}{l}\text { Nilai } \\
\text { MSA }\end{array}$ & $\begin{array}{l}\text { Nilai MSA } \\
\text { minimal }\end{array}$ \\
\hline 1 & $\begin{array}{l}\text { Melepaskan diri dari Rutinitas } \\
\text { kehidupan perkotaan (X1) }\end{array}$ & 0,750 & $>0,5$ \\
\hline 2 & $\begin{array}{l}\text { Melepaskan diri dari rutinitas } \\
\text { pekerjaan (X2) }\end{array}$ & 0,851 & $>0,5$ \\
\hline 3 & $\begin{array}{l}\text { Keinginan untuk penyegaran } \\
\text { fisik dan mental (X3) }\end{array}$ & 0,740 & $>0,5$ \\
\hline 4 & $\begin{array}{l}\text { Keinginan mengunjungi teman } \\
\text { atau krabat (X4) }\end{array}$ & 0,724 & $>0,5$ \\
\hline 5 & $\begin{array}{l}\text { Untuk menunjukan Gengsi } \\
\text { (X5) }\end{array}$ & 0,907 & $>0,5$ \\
\hline 6 & $\begin{array}{l}\text { Keinginan berinteraksi } \\
118 \text { ocal118 dengan masyarakat } \\
118 \text { ocal di Desa Wisata Liang } \\
\text { Ndara (X6) }\end{array}$ & 0,616 & $>0,5$ \\
\hline 7 & $\begin{array}{l}\text { Merealisasikan mimpi-mimpi } \\
\text { yang lama di cita-citakan (X7) }\end{array}$ & 0,680 & $>0,5$ \\
\hline 8 & $\begin{array}{l}\text { Lokasi Desa Wisata Liang Ndara } \\
\text { mudah dijangkau dengan } \\
\text { kendaraan (X8) }\end{array}$ & 0,851 & $>0,5$ \\
\hline 9 & $\begin{array}{l}\text { Tersedianya Rumah makan di di } \\
\text { sekitar Desa Wisata Liang Ndara } \\
\text { (X9) }\end{array}$ & 0,846 & $>0,5$ \\
\hline 10 & $\begin{array}{l}\text { Tersedianya Penginapan di } \\
\text { sekitar Desa Wisata Liang Ndara } \\
\text { (X10) }\end{array}$ & 0,778 & $>0,5$ \\
\hline 11 & $\begin{array}{l}\text { Tersedianya Fasilitas- fasilitas } \\
\text { umum seperti toilet dan tempat } \\
\text { parkir di Desa Wisata Liang } \\
\text { Ndara (X11) }\end{array}$ & 0,803 & $>0,5$ \\
\hline 12 & $\begin{array}{l}\text { Keamanan saat berada di Desa } \\
\text { Wisata Liang Ndara (X12) }\end{array}$ & 0,939 & $>0,5$ \\
\hline 13 & $\begin{array}{l}\text { Keunikan atraksi budaya seperti } \\
\text { tarian Caci atau tarian tradisional } \\
\text { orang Manggarai (X13) }\end{array}$ & 0,952 & $>0,5$ \\
\hline 14 & $\begin{array}{l}\text { Kerajinan tangan berupa tenun } \\
\text { dan anyaman yang dibuat secara } \\
\text { tradisional di Desa Wisata Liang } \\
\text { Ndara (X14) }\end{array}$ & 0,903 & $>0,5$ \\
\hline 15 & $\begin{array}{l}\text { Keindahan Alam disekitar Desa } \\
\text { Wisata Liang Ndara seperti air } \\
\text { Terjun dan hutan lindung (X15) }\end{array}$ & 0,943 & $>0,5$ \\
\hline
\end{tabular}

\section{Sumber: Hasil olah data tahun 2019}

Berdasarkan uji MSA yang telah dilakukan dapat diketahui bahwa 15 indikator faktor pendorong memiliki nilai lebih dari 0,5. Maka semua indikator pendorong tersebut dapat dikatakan sudah memenuhi syarat nilai minimal dari MSA dan dapat digunakan untuk analisis selanjutnya.

\section{Penentuan Jumlah Faktor}

Tabel 5 
Hasil dari penentuan jumlah faktor pendorong pada studi ini dapat dijelaskan pada tabel 6 berikut:

Tabel 6 Penentuan Jumlah Faktor

\begin{tabular}{cccc}
\hline Faktor & $\begin{array}{c}\text { Eigen } \\
\text { Value }\end{array}$ & $\begin{array}{c}\text { Persen } \\
\text { of } \\
\text { variance }\end{array}$ & $\begin{array}{c}\text { Comulative } \\
\text { persen }\end{array}$ \\
1 & 4,815 & 32,100 & 32,100 \\
2 & 3,834 & 25,557 & 57,658 \\
3 & 2,140 & 14,264 & 71,921 \\
\hline
\end{tabular}

Sumber: Hasil Pengolahan Data Tahun 2019

Berdasarkan hasil uji total variance explained ini adalah terbentuk 3 faktor Yang mempengaruhi motivasi wisatawan berkunjung ke Desa Wisata Liang Ndara Kabupaten Manggarai Barat.

\section{Rotasi Faktor}

Hasil rotasi faktor pendorong pada studi ini dapat dijelaskan pada tabel 7 berikut:

Tabel 7 Rotasi Faktor Dengan Metode

\begin{tabular}{|c|c|c|c|}
\hline & & & \\
\hline & & nponent & \\
\hline & 1 & 2 & 3 \\
\hline $\mathrm{X} 11$ & .888 & .236 & .281 \\
\hline $\mathrm{X} 1$ & .809 & .060 & -.090 \\
\hline X14 & .804 & .173 & .361 \\
\hline X13 & .732 & .112 & .202 \\
\hline $\mathrm{X} 12$ & .664 & -.060 & .304 \\
\hline $\mathrm{X} 15$ & .597 & .188 & .118 \\
\hline $\mathrm{X} 5$ & .420 & .076 & .288 \\
\hline $\mathrm{X} 3$ & .074 & .808 & .455 \\
\hline X6 & -.189 & .791 & .069 \\
\hline $\mathrm{X} 2$ & .112 & .785 & .507 \\
\hline $\mathrm{X} 8$ & .525 & .757 & -.046 \\
\hline X9 & .557 & .734 & -.066 \\
\hline X10 & .597 & .722 & .062 \\
\hline $\mathrm{X} 7$ & .223 & .087 & .870 \\
\hline $\mathrm{X} 4$ & .413 & . 390 & .675 \\
\hline
\end{tabular}

Sumber: Hasil Pengolahan Data Tahun 2019

Berdasarkan Tabel 7 hasil analisis rotasi maka dapat dipaparkan bahwa dari ke 15 indikator yang telah di rotasi, terdapat 14 indikator yang memenuhi syarat atau kriteria dan terdapat satu indikator yang tidak memenuhi kriteria dikarenakan loading factor yang tidak mencapai 0,5 , indikator yang dimaksud adalah indikator untuk menunjukkan gengsi (X5).

Faktor yang sudah terbentuk harus diidentifikasi dengan loading factor (korelasi). Maka pada tahapan ini faktor yang merupakan gabungan dari suatu indikator harus diberi nama. Pemberian nama harus mengacu pada indikator yang membentuk faktor yang bersangkutan atau berdasarkan pada indikator yang mempunyai loading factor tertinggi dibandingkan indikator lain yang berada dalam satu faktor tersebut. Interpretasi faktor dapat dilihat pada tabel 8 .

Tabel 8 Loading Faktor Baru

\begin{tabular}{llcc}
\hline & Nama Faktor & Eigenvalue & Variance \\
1) & Kualitas & 4,815 & 32,100 \\
& Fasilitas & & \\
2) & $\begin{array}{l}\text { Istirahat dan } \\
\text { Relaksasi }\end{array}$ & 3,843 & 25,557 \\
3) & $\begin{array}{l}\text { Memwujudkan } \\
\text { Impian }\end{array}$ & 2,140 & 14,264 \\
\multicolumn{2}{l}{ Sumber: Hasil Pengolahan Data Tahun 2019}
\end{tabular}

Berdasarkan tabel 8 dapat ditemukan tiga faktor yang terdiri dari 14 indikator yang mempengaruhi motivasi wisatawan yang berkunjung ke Desa Wisata Liang Ndara Kabupaten Manggarai Barat. Faktor-faktor yang terbentuk diberi nama sesuai dengan indikator yang telah dikelompokkan. Hal ini dapat diuraikan sebagai berikut:

1. Faktor 1

Faktor pertama dinamakan faktor Kualitas Fasilitas, yang terdiri dari beberapa indikator yang meliputi, Tersedianya Fasilitas- fasilitas umum seperti toilet dan tempat parkir di Desa Wisata Liang Ndara (X11), Melepaskan diri dari Rutinitas kehidupan perkotaan (X1), Kerajinan tangan berupa tenun dan anyaman yang dibuat secara tradisional di Desa Wisata Liang Ndara (X14), Keunikan atraksi budaya seperti tarian Caci atau tarian tradisional orang Manggarai (X13), Keamanan saat berada di Desa Wisata Liang Ndara (X12), Keindahan Alam disekitar Desa Wisata Liang Ndara seperti air Terjun dan hutan lindung (X15).

2. Faktor 2

Faktor kedua dinamakan faktor istirahat dan relaksasi yang terdiri dari beberapa idikator yang meliputi, Keinginan untuk penyegaran fisik dan mental (X3), 
Keinginan berinteraksi sosial dengan masyarakat lokal di Desa Wisata Liang Ndara (X6), Melepaskan diri dari rutinitas pekerjaan (X2), Lokasi Desa Wisata Liang Ndara mudah dijangkau dengan kendaraan (X8), Tersedianya Rumah makan di di sekitar Desa Wisata Liang Ndara (X9), Tersedianya Penginapan di sekitar Desa Wisata Liang Ndara (X10).

\section{Faktor 3}

Faktor ketiga dinamakan faktor Mewujudkan Impian yang terdiri dari beberapa indikator yang meliputi, Merealisasikan mimpi-mimpi yang lama di cita-citakan (X7), dan Keinginan mengunjungi teman atau krabat (X4).

\section{Faktor Yang Mendominasi Motivasi Wisatawan Berkunjung Ke Desa Wisata Liang Ndara Kabupaten Manggarai Barat}

Adapun faktor yang mendominasi motivasi wisatawan yang berkunjung ke Desa Wisata Liang Ndara yaitu faktor Kualitas Fasilitas, dengan nilai eigenvalue sebesar 4,815. Faktor Kualitas Fasilitas dengan eigenvalue sebesar 4,815 memiliki 6 indikator diantaranya, Tersedianya Fasilitas- fasilitas umum seperti toilet dan tempat parkir di Desa Wisata Liang Ndara (X11), Melepaskan diri dari Rutinitas kehidupan perkotaan (X1), Kerajinan tangan berupa tenun dan anyaman yang dibuat secara tradisional di Desa Wisata Liang Ndara (X14), Keunikan atraksi budaya seperti tarian Caci atau tarian tradisional orang Manggarai (X13), Keamanan saat berada di Desa Wisata Liang Ndara (X12), Keindahan Alam disekitar Desa Wisata Liang Ndara seperti air Terjun dan hutan lindung (X15).

Tersedianya Fasilitas- fasilitas umum seperti toilet dan tempat parkir di Desa Wisata Liang Ndara termasuk ke dalam faktor yang mendominasi motivasi wisatawan berkunjung ke Desa Wisata Liang Ndara. Berdasarkan hasil penelitian peneliti di lapangan dilihat bahwa fasilitas-fasilitas umum di Desa Wisata Liang Ndara sudah dapat memenuhi segala kebutuhan wisatawan saat berada di Desa Wisata Liang Ndara. Jika dibandingkan dengan daya tarik wisata lain yang ada di Kabupaten Manggarai Barat, Desa Wisata Liang Ndara adalah desa wisata yang memiliki fasilatas-fasilitas pendukung yang sangat baik, hal ini dikarenakan Desa Wisata Liang Ndara merupakan salah satu desa yang menjadi fokus pemerintah dalam pengembangan destinasi wisata yang ada di Kabuapeten Manggarai Barat mengingat lokasinya sangat dekat dengan Labuan Bajo yang merupakan tujuan utama wisatawan berkunjung ke Kabupaten Manggarai Barat. Selain dari pemerintah Kabupaten Manggarai Barat ada juga bantuan dari Kementrian pariwisata pusat untuk penegelolaan dan pengembangan Desa Wisata Liang Ndara, seperti pembangunan homepod sebagai atraksi pendukung untuk menarik wisatawan berkunjung.

Salah satu indikator yang termasuk ke dalam faktor yang paling mendominasi wisatawan berkunjung ke Desa Wisata Liang Ndara yaitu Melepaskan diri dari Rutinitas kehidupan perkotaan. Dapat dijelaskan bahwa banyak wisatawan yang berkunjung ke Desa Wisata Liang Ndara dikarenakan adanya keinginan melepaskan diri dari kegiatan atau aktifitas yang dilakukan sebelumnya di daerah asal, dan mencari tempat yang baru atau sebuah destinasi wisata yang baru untuk melakukan kegiatan berwisata. Dengan keunikan atraksi budaya seperti Tarian, dan Proses pembuatan tenun tradisional yang dimiliki oleh Desa Wisata Liang ndara, menjadikan Desa Wisata Liang Ndara sebagai destinasi yang sangat tepat bagi wisatawan yang ingin mempelajari rutinitas kehidupan masyarakat pedesaan yang masih kental dengan budayanya. Selain atraksi budaya, wisatawan juga dapat menikmati keindahan alam yang ada di Desa Wisata Liang Ndara.

Indikator Kerajinan tangan berupa tenun dan anyaman yang dibuat secara tradisional di Desa Wisata Liang Ndara, termasuk kedalam faktor yang mendominasi wisatawan berkunjung ke Desa Wisata Liang Ndara. Dengan pembuatan tenun yang dilakukan secara tradisional oleh masyarakat Desa Wisata Liang Ndara, memberikan kesan yang sangat menarik bagi wisatawan yang berkunjung ke Desa Wisata Liang Ndara, Hasil dari kerajinan tangan masyarakat Desa Wisata Liang Ndara ini yaitu berupa kain Songke dengan berbagai jenis seperti Sarung, Selendang, dan Peci. Proses Pembuatan tenun khas orang Manggarai Barat ini juga membutuhkan waktu yang sangat lama sampai berminggu-minggu bahkan berbulan-bulan tergantung pada ketersedian benang, 
banyaknnya motif yang digunakan dan kemahiran penenunnya. Alat yang digunakan dalam proses pembuatan tenun khas ini yaitu alat tradisional dirancang sedemikian rupa sehingga dapat digunakan untuk membuat dan menghasilkan sebuah kerjainan tangan yang mempunyai nilai estetis yang tinggi dalam penerapanya.

Keunikan atraksi budaya seperti tarian Caci atau tarian tradisional orang Manggarai, termasuk kedalam faktor yang mendominasi wisatawan berkunjung ke Desa Wisata Liang Ndara. Tarian Caci merupakan tarian yang dimainkan oleh dua laki-laki yang saling bertarung menggunakan cambuk dan prisai. Tarian caci juga menjadi salah satu kesenian tradisional yang cukup terkenal di Pulau Flores, Nusa Tenggara Timur, Karena tarian ini sering di tampilakan di berbagai acara, seperti saat syukuran musim panen, ritual tahun baru, dan berbagai upacara adat lainnya. Secara umum Tarian Caci memiliki makna yaitu untuk menunjukkan kejantanan sehingga tarian ini hanya diperuntukkan bagi laki-laki. Dalam Tarian Caci para penarinya, baik yang memukul maupun dipukul, saling beradu ketangkasan dan kelincahan satu lawan satu.

Indikator Keamanan saat berada di Desa Wisata Liang Ndara, termasuk juga kedalam faktor yang mendominasi wisatawan yang berkunjung ke Desa Wisata Liang Ndara. Seluruh masyarakat di Desa Wisata Liang Ndara tentunya ikut serta dalam mengamankan Desa Wisata Liang Ndara agar wisatawan merasa aman saat berkunjung. Peningkatan keamanan dengan membentuk satuan khusus yang menangani keamanan pariwisata di desa wisata dipandang perlu dilakukan, dan pengamanan ini melibatkan masyarakat ataupun satuan pengaman yang sudah ada (Sagita, 2019:11-12)

Keindahan Alam disekitar Desa Wisata Liang Ndara seperti air Terjun dan hutan lindung, merupakan salah satu faktor yang mendominasi wisatawan berkunjung ke Desa Wisata Liang Ndara. Keindahan alam yang ada di Desa wisata Liang Ndara seperti air terjun dan hutan lindung menjadi faktor penarik motivasi wisatawan berkunjung, dan menjadi daya dukung Desa Wisata Liang Ndara. Keindahan alam yang terdapat di daya tarik wisata seperti pemandangan alam yang indah, merupakan motivasi penarik bagi wisatawan yang ingin berkunjung ke suatu destinasi wisata (Wijaya dkk, 2017:89).

\section{SIMPULAN DAN SARAN Simpulan}

Terdapat tiga faktor yang mempengaruhi motivasi wisatawan berkenjung ke Desa Wisata Liang Ndara yaitu 1. Faktor pertama dinamakan faktor Kualitas Fasilitas yang terdiri dari enem indikator yaitu: Tersedianya fasilitas- fasilitas umum seperti toilet dan tempat parkir di Desa Wisata Liang Ndara, Melepaskan diri dari Rutinitas kehidupan perkotaan, Kerajinan tangan berupa tenun dan anyaman yang dibuat secara tradisional di Desa Wisata Liang Ndara, Keunikan atraksi budaya seperti tarian Caci atau tarian tradisional orang Manggarai, Keamanan saat berada di Desa Wisata Liang Ndara, Keindahan Alam disekitar Desa Wisata Liang Ndara seperti air Terjun dan hutan lindung, 2. Faktor kedua dinamakan faktor Istirahat dan Relaksasi yang terdiri dari enam indikator yaitu: Keinginan untuk penyegaran fisik dan mental, Keinginan berinteraksi sosial dengan masyarakat lokal di Desa Wisata Liang Ndara, Melepaskan diri dari rutinitas pekerjaan, Lokasi Desa Wisata Liang Ndara mudah dijangkau dengan kendaraan, Tersedianya Rumah makan di di sekitar Desa Wisata Liang Ndara, Tersedianya Penginapan di sekitar Desa Wisata Liang Ndara. 3. Faktor ketiga dinamakan Mewujudkan Impian yang terdiri dari dua indikator yaitu: Merealisasikan mimpimimpi yang lama di cita-citakan, dan Keinginan mengunjungi teman atau krabat.

Faktor dominan yang mempengaruhi motivasi wisatawan berkenjung ke Desa Wisata Liang Ndara adalah faktor Kualitas Fasilitas dengan nilai eigenvalue sebesar 4,815 dengan memiliki persentase variance sebesar 32,100 persen. Faktor tersebut terdiri dari enem indikator yaitu, Tersedianya Fasilitas- fasilitas umum seperti toilet dan tempat parkir di Desa Wisata Liang Ndara (X11) dengan loading factor 0,888, Melepaskan diri dari Rutinitas kehidupan perkotaan (X1) dengan loading factor 0,809, Kerajinan tangan berupa tenun dan anyaman yang dibuat secara tradisional di Desa Wisata Liang Ndara (X14), dengan loading factor 0,804 , Keunikan atraksi budaya seperti tarian Caci atau tarian tradisional orang Manggarai (X13) dengan loading factor 0,732 Keamanan saat berada di Desa Wisata Liang 
Ndara (X12) dengan loading factor 0,664, Keindahan Alam disekitar Desa Wisata Liang Ndara seperti air Terjun dan hutan lindung (X15) dengan loading factor 0,597.

\section{Saran}

Berdasarkan hasil wawancara dengan beberapa wisatawan yang berkunjung ke Desa Wisata Liang Ndara, didapatkan hasil bahwa adanya keluhan yang disampaikan wisatawan yang berkunjung menggunakan sepeda motor mengenai sulitnya menemukan lokasi dari dari Desa Wisata Liang Ndara. Sehingga diharapkan agar fasilitas pendukung seperti plang petunjuk jalan menuju Desa Wisata Liang Ndara perlu diperhatikan dengan baik.

Masuknya budaya baru menghilangkan secara perlahan tradisi turun temurun yang diwariskan nenek moyang masyarakat Desa Wisata Liang Ndara, hal ini dapat dilihat dengan sedikitnya penenun khas tradisional di Desa Wisata Liang Ndara. Berdasarkan hasil wawancara dengan beberapa wisatawan yang berkunjung ke Desa Wisata Liang Ndara, mereka mengatakan bahwa, masyarakat harus tetap menjaga keaslian budayanya. Sehingga kedepanya diharapkan agar pengelolah Desa Wisata Liang Ndara melakukan penyuluhan dan pelatihan kepada masyarakat di Desa Wisata Liang Ndara agar tetap menjaga dan mempertahankan kearifan budayanya, yang memiliki keunikan tersendiri dan mampu menarik wisatawan berkunjung.

Diharapkan bagi peneliti selanjutnya untuk memasukan indikator kebersihan sebagai salah satu indikator motivasi wisatawan berkunjung, karena berdasarkan hasil komentar dan saran pada kuesioner yang dibagikan kepada wisatawan, begitu banyak wisatawan yang menyarankan agar menjaga kebersihan di Desa Wisata Liang Ndara, dan untuk pengelola Desa Wisata Liang Ndara diharapkan untuk melakukan sosialisasi penanganan sampah terhadap masrakat di Desa Wisata Liang Ndara, karena masih kurangnya perhatian masyarakat dengan kebersiahan Desa Wisata Liang Ndara 


\section{Kepustakaan}

Anggela, M.M., Karini, N.M.O. and Wijaya, N.M.S., 2018. Persepsi dan motivasi wisatawan yang berkunjung ke daya tarik wisata Jembong di kabupaten Buleleng. Jurnal ipta, 5 (2), pp. 76-91.

Crompton, J. L. 1979. Motivations for Pleasure Vocations. Annals of Tourism Research. Vol. 6, No.4.

Mcintosh. 1977. Karakteristik Wisatawan. Yogyakarta: Penerbit Andi

Pitana, I Gde. 2005. Sosiologi Pariwisata, Kajian Sosiologis Terhadap Struktur, System, Dan Dampak-Dampak Pariwisata. Yogyakarta: Andi offset.

Pavule, Giva. 2006. International Tourism Market for camping sites in Latvia. Bornemouth University. Hochschule Heilbronn

Rochaety E, dkk. 2007. Metodologi Penelitian Bisnis: Dengan Aplikasi SPSS, Edisi Pertama. Penerbit Mitra Wacana Media: Jakarta

Sagita, P.A.W., 2019. Strategi Pengembangan Desa Pangsan Sebagai Desa Wisata Di Kecamatan Petang Kabupaten Badung. Spillane, James J. 1997. Pariwisata Indonesia. Kanisua. Yogyakarta.

Sugiyono. 2013. Metode Penelitian Kuantitatif, Kualitatif dan $R \& D$. Bandung: Alfabeta. CV
Santoso, 2006, Menggunakan SPSS Untuk Statistic Non Parametric, Jakarta: PT. Elex Media Komputindo.

Umi Narimawati, 2008. Metodologi Penelitian Kualitatif Dan Kuantitatif, Teori Dan Aplikasi. Bandung: Agung Media.

Undang-undang Republik Indonesia No.10 Tahun 2009 tentang Kepariwisataan. 